\title{
Bibliographie choisie sur l'enseignement supérieur au Canada \\ Select Bibliography of Higher Education in Canada
}

\author{
D. MCCORMACK SMYTH, HAZEL ROBERTS, PIERRE CASNO*
}

This bibliography follows the one pubblished in The Canadian Journal of Higher Education (formerly called Stoa), Vol. V, no. 1, 1975, pp. 73-81. References are listed as in Robin S. Harris, A Bibliography of Higher Education in Canada, Supplement 1971 , but the following categories have been added:
Cette bibliographie continue celle qui a paru dans La Revue canadienne d'enseignement supérieur (précédemment Stoa), Vol. $\mathrm{V}$, no. 1, 1975, pp. 73-81. Les références sont données comme dans Robin S. Harris, Bibliographie de l'enseignement supérieur au Canada, Supplement 1971. Les catégories suivantes ont été ajoutées:

2H Access to Higher Education / Accès à l'enseignement supérieur

3L Canadian Studies / Etudes canadiennes

4J Scholarly Publication / Revues savantes

6E Collective Bargaining/ Négociation collective

\section{I - DEGREE-GRANTING UNIVERSITIES AND COLLEGES UNIVERSITES ET COLLEGES QUI CONFERENT DES GRADES}

\section{History and Organization / Histoire et organisation}

A General / Géneralités

"Canadian Universities should develop new international ties. Univ/Aff/Aff. Univ. $16(9): 9$

"International academic links." Association Internationale des Université Bulletin / International Association of Universities. 23(1):19-22

Jackson R. W. "The only place that combines learning and teaching at the highest level." Univ. Aff / Aff. Univ. 16(8):7

The Khaki University in the United Kingdom: an experiment in post-war army education, 1945-1946. Edited by J. R. Petrie. Leavesden, Herts., England, Khaki University of Canada, 1946, 224 leaves. mimeographed.

*D. McCormack Smyth is Professor of Administration, Atkinson College, York University.

Hazel Roberts is Head Librarian, Association of Universities and Colleges of Canada.

Pierre Casno, Faculté des Sciences de l'Education, Université de Montréal. 
Lebel, M. "Influence sur les universités canadiennes." Mémoires de la Société Royale du Canada. Série 4, tome 11:4363

Ontario Department of Public Records and Archives, A Guide to pamphlets in the Ontario Archives relating to educational History 1803-1967. Prepared by Roy Reynolds. Toronto, Ont. Department of History and Philosophy, O.I.S.E.

Ontario Department of Public Records and Archives. Items relating to education in private papers in the Ontario Archives: A Guide to Sources in educational History from the private manuscripts section of the Archives of Ontario. Prepared by Roy Reynolds, Toronto, Ont. Department of History and Psychology. O.I.S.E.

"Presenting the Canadian National Commission for Unesco." Unesco Chronicle 20(7-8): 287-289

Ridout, G. et al. "Sir Ernest MacMillan 1893-1973." Canadian Composer. No. 82 (July) Whole issue devoted to MacMillan.

Sheldon, Mivhael. "Mythe and consequence". Univ. Aff/Aff. Univ. 16(5):28

Volpe, R. et al. "The new medical schools in Canada." Modern Medicine of Canada $26(2): 19-23,25$

\section{B The Atlantic Provinces / Les provinces atlantiques}

Bruce, H. "The way we were at Mount Allison." MacLeans 87(9):22-23, 56, 58

Dearborn, D. "UNB's Saint John Campus is getting all together." The Atlantic Advocate $65(7): 23,25,26$

Gleason, M. "Complete 10 years at University of Moncton." The Atlantic Advocate 63 (8):32-34, 35

Gleason, Marie. "MUN introduces new community learning centre project." Univ. Aff / Aff. Univ. 16(4):6

Guttman, M.A.J. "A Survey of selected school counsellor training programs in Canadian universities." Canadian Counsellor 7(4):250-57

Hayes, F. R. "Two Presidents, two cultures, and two wars: a portrait of Dalhousie as microcosm of twentieth-century Canada." Dalhousie Rev. 55(3):407-17

Major, M., Lorne, G., and Braddock, J. "Dalhousie Law School - training ground for Premiers?" The Atlantic Advocate 82(3):10-18

Holmes, Jeffrey. "Opposing 'campus' debate future of MUN." Univ. Aff/Aff. Univ. $16(4): 7$

McKenna, M. D. "The History of higher education in the Province Prince Edward Island." Canadian Catholic historical Association (annual report) No. 36:19-50

Rogers, Jerry. "Too many universities in the Maritimes?" The Atlantic Advocate 62(9):21-22

C The Universities of Quebec/Les Universités du Québec

Côte, J. "La femme dans les universités québécoises". Univ. Aff / Aff. Univ. 16(8):5

Daoust, Gaétan. L'éducation permanente et l'université québécoise. A la recherche de stratégies. Montréal. P.U.M., 1975, 305p.

Gingras, Pierre et Lipkin, John P. "Thèse et antithèse: le conseil des Universités et les Universités québécoises face à l'éducation permanente." STOA 4(1):69-74

Guérin, Gilles. "Bibliographie critique des modèles de prévision des effectifs etudiants au niveau universitaire." STOA 4(1):55-68

\section{The Universities of Ontario / Les Universités de l'Ontario}

Gilbert. G. T. "Problems of implementing Ontario's new educational programme." Canadian Chartered Accountant. 100(5):57-62

Kramer, James R., and O. Mudrock. "Asbestos research at McMaster University". Canadian Research and Development. 7(6) (Nov./Dec. '74):31-32 
Neatby, H. "Queen's College and the Scottish fact". Queen's Quarterly. 80:1-11 "OCUA tackles single most contentious issue". Univ. Aff / Aff. Univ. 16(5):12-13 "OCUFA brief to the Ontario Council on University Affairs." OCUA Newsletter 8(2) (special supplement, Nov. '74):1-4

\section{E The Universities of Manitoba / Les Universités du Manitoba}

"University of Manitoba concerned about financial situation." Univ. Aff. / Aff. Univ. $16(5): 6$

\section{Current Trends and Problems / Orientation et problèmes présents}

\section{A General / Généralités}

Auster, Bett, and Lawton, B. "Inside Information". Canadian Education. 15(1):39-42

Booth, A. D. "Some thoughts on university education". The Lakehead University Review. 6(2):191-208

Cloutier, Jean. "L'audio-visuel à l'université". Prospectives 11(1):24-37

Cloutier, Jean. L'êre d'Emerec ou la communication audio-scriptovisuelle à l'heure des self-media. 2e éd. Montréal, Qué. PUM. 1975, 256p.

Echard, G. "Intercommunication at the high school and university levels 'Possibility or Pipedream!"' Canadian Modern Language Review. 27(3):32:35

"Equal pay for equal work." Unesco Courier. Mar. '75:1017

Fairweather, G. P. "Post-secondary education: Ottawa musn't back off." Canadian Business. 45(7) (July '72):25-26

Harlow, R. "Universities rediscover the old values". MacLeans. 86(10):6

Harvey, E. B. "Canadian higher education and the seventies." Interchange 5(2):45-52

"The image of Universities: five Presidents answer the questions". The Atlantic Advocate. 65(10): 18-24, 26-

Lebel, M. "La révolution sur le campus." Mémoires de la Société Royale du Canada. Série 4, tome 9:155-70

Mackay, Colin B. "Executive Director's report". AUCC Proc. 1974. 2:19-24

Mackay, Colin B. "Rapport du directeur administratif." A UCC Proc. 2:12-17

McLeod, E. M. A Study of child care service at canadian universities. Ottawa, Ont., Association of Universities and Colleges of Canada, 1975.43p.

Neatby, H. "Frustrated, prejudiced, partial, biased and undemocratic: some personal reflections on the predicament of our Universities." Transactions of the Royal Society of Canada. Series 4, vol. 10:137-47

"Professors beware! you and your friendly cable company." CAUT / ACPU Bulletin. $23(4): 2$

Schroeder-Gudehus, B., "Le paradox. De la croissance universitaire" STOA 4(2):9:20

Shaw, R. F. "Crisis in the university". Library Association of Alberta Bulletin. 1(2) (Oct '69):18-26

Stamp, R. M. "Canadian universities and canadian identity." Canadian and International Education. 3(1):17-33

Status of women in Canadian Universities; background paper for the AUCC annual meeting, Ottawa, Oct. 29-30, 1975 / La situation de la femme dans les universitées canadiennes; rapport documentaire pour l'Assemblée annuelle de l'AUCC, Ottawa, les 29 et 30 oct. 1975. Ottawa, Ont., AUCC, 1975. 71 p.

Sullivan, N., "Student radio stations granted 'restricted' commercial FM licenses." Univ. Aff / Aff. Univ. 16(8):15

Sullivan, N. "Status of women in the University; progress is being made." Univ. Aff. / Aff. Univ. 16(8):2-4 
Wallace, C. "President's report." AUCC. Proc. 1974, 2:15-18

Wallace, C. "Rapport de la présidente." AUCC. Proc. 1974. 2:7-11

"Women and illiteracy; women and the steps to education." Unesco Courier. 5:18-19

"Women at University." Unesco Courier. Mar. '75:20

Women in canadian Universities; a statistical compendium / La femme dans l'Université canadienne; un compendium statistique. Prepared by Statistics Canada in co-operation with the Association of Universities and Colleges of Canada / Préparé par Statistique Canada en collaboration avec l'Association des Universités et Collèges du Canada. Ottawa, Ont., AUCC, 1975. 165p.

"Women in higher education." A special report. CAUT / ACPU Bulletin. 24(1):6-26

\section{B University Government / Administration universitaire}

Heasman, D. J. "Liberty, authority and democracy; the involement of students in university government." CAUT / ACPU Bulletin 23(6):10-12

\section{University Finance / Finances universitaires}

"Federal support of universities and colleges / L'aide du gouvernement fédéral aux universités et collèges." CAUT/ACPU Bulletin 23(4):17-22

"Government and education." The Atlantic Advocate. 63(9) (May '73):20-22, 42 (Extract of remarks made by Senator Hicks, President of Dalhousie University, in Senate importance of federal government to support the post-secondary education.)

\section{The University and the State / L'Université et l'Etat}

Bennet, Greg. "Ontario asserts science policy control" Ontario Confederation of University Faculty Associations, Newsletter 8(3):1

Ouellette, Y. "Le contrôle judicaire sur l'université." The Canadian Bar Review. $48(4): 631-50$

Trotter, Bernard. Planning for planning; relationships between Universities and Governments: guidelines to process. Ottawa, Ont., Association of Universities and Colleges, 1974. $84 \mathrm{p}$.

Trotter, Bernard. Planifier pour planifier; les relations entre les universités et les gouvernements; leurs lignes directrices. Ottawa, Ont., L'Association des Universités et Collèges du Canada, 1974. 89p.

"Universities must bear more aggressively." Univ. Aff / Aff. Univ. 16(9):24

Watts, R. L. "Freedom with responsibility: universities government and public." Queen's Quarterly. 82(1):14-21

Woodcock, Lynda. "Advisory body critical of Government policy." Univ. Aff / Aff. Univ. $16(5): 2-3$

\section{$\mathrm{G}$ University Planning / La planification universitaire}

"Evolution des inscriptions d'ici l'an 2000." Univ. Aff / Aff. Univ. 16(9):7

Hiebert, G. P. "Organization for planning: an outline of the planning process employed by McMaster University Health Science Centre." Canadian Hospital. 49(4) (April '72): 64-66, 69-71

Matthews, A. W. "The role, organization and support of university athletic programs." AUCC Proc. 1974, 2:32-40

Matthews, A. W. "Le rôle, l'organisation et l'appui des programmes sportifs des universités." AUCC Proc. 1974. 2:25-33

Trotter, B. and Carruthers, A.W.R. Planning for planning. Ottawa, Ont., 1974. 84p.

Woodcock, L. "Universities must prepare for enrolment fluctuations." Univ. Aff / Aff. Univ. 16(9):6-7 
Workshop on the Study of athletic programs in canadian Universities, Ottawa, Ont., 1974. / L'atelier sur l'étude des programmes sportifs dans les universités canadiennes, Ottawa, Ont., 1974. Proceedings / Délibérations, sponsored by the Association of Universities and Colleges of Canada and the Canadian Intercollegiate Athletic Union. Ottawa, Ont., AUCC, 1974.

\section{H Access to Higher Education / Accès à l'enseignement supérieur}

Bradley, E., "Repatriating Education: the standard of New Jersey." MacLeans 87(11) (Nov. '74):12

Lamontagne, L., "La technologie et l'accès aux études postsecondaires." Mémoires de la Société Royale du Canada. Série 4, tome 7:87-91

\section{Curriculum and Teaching / Programme d'étude et méthodes d'enseignement}

\section{A General / Généralités}

Lucas, A. "Curriculum Crisis." Canadian Dimension. 8(2):58-60

Sullivan, Arthur. "Foundation courses prove great help to first year students." Univ. Aff / Aff. Univ. 16(4):14-15

B The Faculty of Arts and Sciences / Faculté des Arts et des Sciences

"Riting skills disapeering." Univ. Aff / Aff. Univ. 16(3):28

\section{The Humanities / Les humanités}

Adaskin, J. et al. "A tribute to Sir Ernest MacMillan." Music across Canada 1(6):16-39

Black, J. L. "Slavic studies at Laurentian University." The New Review 9(4):301-05

Bornstein, E. "Seriography - why a new university course attracts artists in Saskatchewan?" Canadian Art 14(3):98-100

Fellows, J. A. "A loyalist studies resurgence in a loyalist Province." The Atlantic Advocate 63(5) (Jan. '73):19-21

George, G. "Queen's University's new degree: Bachelor of Music." Canadian Music Educator $10(4): 27-28$

Kemp, W. H. "University choral music with the university choir." Canadian Music Educator $10(1): 17,19-21$

O'Neill, M. "Literature or language? french at the undergraduate level." Canadian Modern Language Review 27(3):36-37

Orchard, G. E. "Slavic studies in Alberta Universities." The New Review 8(3):136-38

Perkyns, D. "Duo personality". The Atlantic Advocate 63(8) (Apr. '73):15-16

Siess, T. F. and Stone, G. L. "Evolution of a Counseling Psychology programme." Ontario Psychologist 6(5):47-58

Stern, H. H. "The OISE modern language center today." Canadian Modern Language Review 27(3):74-78

"Teacher training is prime role of Laval's School of Music." Canadian Music Educator 13(4) (Summer '72):7-8

White, J. R. "Under a new roof." Performing arts in Canada 10(1):27-28

Wine, J. J. "Canada's graduate school of Psychology." Ontario Psychologist 6(5):6-34

Woloch, M. "Byzantine studies in Canada." The New Review 8(1-2) (June '68):75-77 
D Social Sciences / Sciences sociales

Clarkson, S. "Lament for non-subject: reflections on teaching Canadian-American Relations." International Journal 27(71/73): 265-75

Weinstein, W. "Non-neutral talking shops." CAUT / ACPU 23(4):11-12

E Mathematics and the Sciences / Mathématiques et sciences

Babitt, J. D. "Rationalism: the fallacy behind Canadian science policy." Canadian Research and Development 8(1)30-32

Borstel, R. C. von. "A survey shows how feeble funding cripples University biology departments." Science Forum 8(1):3-6

McQueen, H. "Engineering education: changes logging behind." Univ. Aff / Aff. Univ. $16(3) 4-5$

"New MRC programs / Nouveaux programmes du CRM". Medical Research Council Newsletter / Actualités Conseil de recherche médicale 5(3):1-4

"Saskatchewan committee recommends system for renewing medical licenses," Univ. Aff / Aff. Univ. 16(4):8

Syllivan, N., "Limiting foreign doctors seen as partial answer to health care question." Univ. Aff / Aff. Univ. 16(4):5

\section{F Professional Education / Enseignement professionel}

"Agreement reached on legal education." Univ. Aff / Aff. Univ. 16(2):7-8

Anderson, G. J. and Lauwerys, J. A. "Altering the structure of Teacher Education: A Case Study from Atlantic Canada," Interchange 4(2-3):88-98

Bates, D. G. "Humanism in undergraduate medical education." Canadian Medical Associa. tion Journal 105(3):7, 258-61

Bonneau, L. Ph. "La santé et l'Université." Univ. Aff / Aff. Univ. 16(2):2-4

Boxen, G. and Kronol, M. "Man, the adapter in the home economics Curriculum." Canadian Home Economics Journal 24(2):11-14

Brehaut, W. "Problems of Teacher Education in Canada's smallest Province." Interchange $4(2-3): 79-87$

Bremer, A. "The pilot programe for Teacher Education at Dalhousie University." Interchange 4(2-3): $99-105$

Chalke, F.C.R. "The growth and development of behavioural science in medical education." Canadian Psychiatric Association Journal 15(6):581-85

Cochrane, W. W. "Educating the providers of tomorrow's family health care." Canadian Family Physician 18(1):32-36

Collishaw, N. E. and Grainger, R. M. "Enrolments in Canada's medical schools, 1970-71." Canadian Medical Association Journal 106(2):163-68

Collishaw, N. E. and Grainger, R. M. "Enrolments in Canada," 1970-71. "Canadian Meidcal Association Journal" 106(2):153-54, 156, 159-61

Collishaw, N. E. and Grainger, R. M. "Medical student enrolment in Canada, 1969-1970. Canadian Medical Association Journal 104(10):916-22

Connolly, P. H. "The recruitment and selection of personnel for academic liberties." Library Association of Alberta Bulletin 3(2-3):9-19

Council on Education. "Proposals for specialization in dentistry." Canadian Dental Association Journal 37(4):135-37

Ebert, R. H. "The medical school and the community." Canadian Medical Association Journal 105(2):151-54

Eckel, L. G. "The university accounting curriculum." Canadian Chartered Accountant 97(1):23-27

Gleason, M. "Flexible content in New Y of M. engineering course." The Atlantic Advocate 62(11):69 
Gourley, J. M. "Co-ordination of dental materials science and techniques with clinical dentistry at the freshman level. Canadian Dental Association Journal 39(2):120-22

Guttman, M.A.J. "A survey of selected school counselor training programs in Canadian universities." Canadian Counsellor 7(4):250-57

Ham, J. M. Lapp, P. A., and Thompson, I. W. Careers of engineering graduates 1920-1970 University of Toronto. The Engineering Alumni University of Toronto, 1973. 89p.

Hillenbrand, H. "The canadian fund for dental education: a leadership challenge for the profession." Canadian Dental Association Journal 37(9):322-23

LaSalle, G. "Rôle de l'université face aux problèmes du domaine de la santé." Canadian Hospital 47(8):71-72

Longmore, A. J. "Retraining teachers-point to ponder." Education Canada 14(4)18-19

McRae, D. M. "The law school and the university and law courses for undergraduates. University of Toronto Law Journal 21:529-42

Neill, S. "Practice or principle - the elimination of library schools as training grounds."

British Columbia Library Journal 34(4):32-37

Overing, R.L.R. "Towards a redefinition of teacher education." Interchange 4(2-3):19-27

Parenteau, R. "L'influence étatsunienne dans les écoles d'administration au Canada et plus particulièrement au Québec." Mémoires de la Société Royale du Canada. Série 4, tome 11:109-17

Paynter, K. J. "New era in canadian dentistry." Canadian Dental Association Journal $38(10): 357,359$

Rusted, I. E. Roberts, K. R., and Cox, A. R. "A combined three year and four year medical programme with modified admission requirements." Canadian Medical Association Journal 108(11) 1420-22

Sharpe, L. E. "Continuing education in dentistry: an attitude survey in British Columbia." Canadian Dental Association Jounral 38(10):373-75

Sims, J. et al. "Dialogue". Canadian Dental Association Journal 37(12):437-39

Sullivan, N. "And who shall enter?" Univ. Aff / Aff. Univ. 16(8):8-10

Uprichard, M. "The education of Nurses." The Canadian Nurse 68(6):30-36

Vaillancourt, de G. "Open circuit television in medical education a five year experience." Canadian Family Physician 18(2):34-36

Wright, J. G. "A statement on the need for librart education programmes in Alberta during the next decade 1971-1981 Library Association of Alberta Bulletin 3(2-3):4058

\section{G Graduate Studies / Grades supérieurs}

Dick, W. "Graduate training in psychology." Ontario Psychologist 6(5):5

Safarian, A. E. "A perspective on graduate studies in Canada." Journal of Canadian Studies 9(1):42-52

Stern, H. H. "The OISE modern language center today." Canadian Modern Language Review 27(3):74-78

\section{H Adult Education / Education des adultes}

Cawwod, Joe and Stewart B. C. "The school administration - andragogue." Education Canada 15(1):34-37

Cumming, L. S. "Continuing education; community service and the university." CAUT / ACPU Bulletin 23(5)12-14

Daoust, Gaétan et Bélanger, $P$. "L'éducation des adultes ou l'éducation permanente; l'université québécoise à la croisée des chemins?" CAUT / ACPU 23(5):15-16

Devlin, L. E. "The continuing education function; some implications." CAUT / ACPU Bulletin 23(5): 10-12

Drummond, J. M. "Part-Time studies: education as consumer good." CAUT / ACPU Bulletin 23(5):24-25 
Ferland, M. "L'éducation des adultes dans les universités du Canada." CAUT / ACPU Bulletin 23(5):0-10

Kiely, M. C. "A programme of college education for mothers with small children: an evaluation of its effects on mental health." Canadian Counsellor 8(4):240-49

Koenig, D. M. "Adult education in the north: Cinderella needs a glass slipper." CAUT / ACPU Belletin 23(5):17-18

Lotz, J. "Extension and 'in-tension' on the campus: some observations." CAUT / ACPU Bulletin 23(5):16-17

MacCormack, J. R. "Education the public: universities and the mass media." CAUT / ACPU Bulletin 23(5):19-20

Sapper, L. "Adult education in Britain: the open university." CAUT / ACPU Bulletin 23(5):23-24

Sullivan, R., "The mountain comes to Mohammed: tele-education at Scarborough public library." Canadian Library Journal 23(2):115-116

\section{Research and Scholarship / Recherche et études}

\section{A General / Généralités}

"CAUT position on federal research policy / Politique de l'ACPU sur la position fédérale en matière de recherche." CAUT / ACPU Bulletin 23(4):13-14

Faulkner, J. H. "Luncheon address". AUCC Proc. 1974. 2:41-47

Faulkner, J. H. "Adresse". AUCC Proc. 1974. 2:34-40

Woodcock, L. "Assessing the future in aid of public policy. Univ. Aff / Aff. Univ. $16(4): 4$

\section{Sciences / Sciences}

"Moral and ethical dimensions of scientific enquiry becoming dominant factors." Univ. Aff / Aff. Univ. 16(8):7

Winspur, W. "Evolution of a pooled computer system for life science research." Canadian Research and Development 8(2):15-17

D In the Humanities and the Social Sciences / Humanités et sciences sociales

Francis, W. "The expanding spectrum: literary magazines." Canadian Literature 57:6-17 Stevenson, R. W. "Shastri Indo-Canadian Institute." Univ. Aff / Aff. Univ. 16(3):10

\section{E In education / Enseignement}

Bélanger, P. "Recherche en éducation des adultes à Québec." Convergence 7(2):39-46

F Libraries / Bibliothèques

Connolly, P. H. "An attempt to design a low-cost alternative to the standard academic library." Library Association of Alberta Bulletin 3(4):7-17

Gifford, H: "Canadian participation in IFLA: its growth and problems." Canadian Library Journal 32(2)127-131

Bignell, D. C. "The use of MARC II at the University of Saskatchewan, Saskatoon Campus." Saskatchewan Library 24(1):3-8

Lowsley, J. "University library extension services." Library Association of Alberta Bulletin 2(3):1-7

McKinlay, J. "The science fiction collection at the University of British Columbia." British Columbia Library Journal. 34(4):5-19

Murray, O. B. "The social context of the university library." Library Association of Alberta Bulletin 2(1):34-56 
Robbins, J. E. "Library service in Manitoba." Canadian Library Journal 32(2):115-116

Stokes, R. "The road ahead?" British Columbia Library Quarterly 37(1-2):5-16

"University libraries and pressure groups." Univ. Aff / Aff. Univ. 16(4):9

Wallace, E. "An educational resource centre for University of New Brunswick." Atlantic Province Library Journal 38(4):103-04

Wick, D. E. "The learning resource centre in the University of Lethbridge." Library Association of Alberta Bulletin 4(1):19-26

Wiehs, J. R. "The college-trained library technician." Atlantic Provinces Library Association Bulletin 38(2):45

Wiseman, J. A. "Community use of university libraries." Canadian Library Journal $32: 373-376$

G Museum

Goulding, W. "The university as an interpretive patron." Canadian Art 19(3)218-221

J Scholarly Publishing / Revues savantes

Collin, C. et Osana, Z. L'Enseignement de la philosophie. Essai de didactique expériemental. Montréal, Qué., Les Editions Fides, 1974

Montagnes, I. "The university presses." Canadian Literature nos 5-7:18-28

Thornton, A. P. "A reserved occupation." International Journal 30(1)1-14

\section{The Student and Student Services / L'étudiant et les services aux étudiants}

\section{A General / Généralités}

Corfield, V. K. and Ogston, D. G. "Personality camelotes of academic stability among university freshmen." The Canadian Psychologist 14(3):281-89

Dodge, D. A. and Stager, D. A. A. "Economic returns to graduate study in science engineering and business." Canadian Journal of Economics 5(2)182-98

Mclntosh, B., Wilson, L. N. and Lipinski, B. G. "The extent and nature of student attrition in the first five years at Simon Fraser University." Canadian Counsellor 8(3): $163-174$

Perkins, S. A. "The academic performance of first year university students: a comparative analysis." Canadian Counsellor 7(3):184-91

"Report on the fourth annual Canadian dental student's conference." Canadian Dental Association Journal 39(5):323, 324, 326, 328

Vikis-Freibergs, Vaira. Fréquence d'usage des mots au Québec. Etude psycholinguistique d'un échantillon de la région montréalaise. Montréal, Qué., P.U.M., 1974. 156p.

Well, A. V. and Sartoris, P. C. "Study of withdrawing students for the University of Alberta 1970-71 session." Canadian Counsellor 7(1):40-48

\section{E Counseling and Guidance / Orientation}

"Guidelines for Canadian university counselling services." The Canadian Psychologist 14(1):87-92

Waxer, P. and White, R. "Introducing psychological counsultation to a university community." The Canadian Psychologist 14(3)256-65

\section{F Placement / Emploi}

Yarmey, A. D. "Appreciation of university education in relation to employment expectations." The Canadian Psychologist 15(2):165-77 
6 The Professor and Conditions of Work / Le Professeur et les conditions de travail

A General/Généralités

"CAUT / CACUL join on academic status for librarians." CAUT / ACPU Bulletin 24(1):3

C Academic Freedom/ Libertés universitaires

Cinman, I. "U. of Q. reforms cause rift in faculty-administration relations." CAUT / ACPU Bulletin 23(6):7

Cinman, I. "Victory in the Supreme Court." CAUT / ACPU Bulletin 23(5):1-2

Shore, B. M. "Moving beyond the course evaluation questionnaire in evaluating university teaching." CAUT / ACPU Bulletin 23(4):7-10

D Salary and Benefits / Salaires et bénéfices

Bowen, N. V. "Correcting salary anomalies: do we rob Peter to pay Paula?" OCUFA newsletter 8(2):2-3

"Firing followed years of "warnings"" Univ. Aff / Aff. Univ. 16(2):16

"Sessional, limited term appointments may lead to tenure quotas." CAUT / ACPU Bulletin 23(6):3

Sullivan, N. "Faculty salaries lag behind the cost of living." Univ. Aff / Aff. Univ. $16(5): 4-5$

E Collective Bargaining / Négotiation collective

"Carleton faculty vote for unions" CAUT / ACPU Bulletin 23(5):1 Cinman, I1, "Carleton faculty certified: Ontario Labour Board defines faculty union composition." CAUT / ACPU Bulletin 24(1):1-2

Cinman, I. "Carleton staff members endorse union." CAUT / ACPU Bulletin 23(6): 1-9

"Court clears way for union" (at University of St. Thomas in Fredericton). CAUT / ACPU Bulletin 24(1):1

Crispo, J. "Collective bargaining by professionals: advisability, practicability and feasibility." CAUT / ACPU Bulletin 23(6): 12-14

Cross, M. S. "The strange case of Seeley." The Canadian Forum 54(649):4-5

Leahey, P. "FAPUA strengthened by affiliation votes." CAUT / ACPU Bulletin 23(6):1-2

Meyers, D. "OISE and John Seeley." The Canadian Forum 54(649):1-2

Pierre, G. "At Manitoba, faculty sign first collective agreement: Comprehensive contract provides for greater participation." Univ. Aff / Aff. Univ. 16(9):2-3

"St. Mary's faculty sign collective agreement." CAUT / ACPU Bulletin 23(4):1-2

"Syndicalisation à l'Université de la Colombie Britannique." CAUT / ACPU Bulletin 23(4):3,6

\section{II - NON-DEGREE GRANTING INSTITUTIONS / ESTABLISSEMENTS QUI NE CONFERENT PAS DE GRADE}

\section{General / Généralités}

Giroux, R. F. "New directions for disadvantaged adults in the community college." Canadian Counsellor 8(3):156-62

Johnston, E. F. "Community college environment - neglected research in Canada." Canadian Counsellor 6(2):100-111 


\section{Québec / Quebec}

Arpin, R. "Trois hypothèses concernant la place des services aux étudiants dans un Cegep." Prospectives 7(4):205-210

Bélanger, G. "Réflexions sur l'implantation des Cegep." Prospectives 6(4):262-63

Bélanger, P. et Paquet, P. "Problématique de l'éducation des adultes dans les Cegep." Prospectives 6(2): 104-21

Boucher, R. "Le collège-bibliothèque, une solution cadre". Prospectives 6(5):341-48

Bouthillier, G. et Maynaud, J. Le choc des langues au Québec (1760-1970). Montréal, Qué., P.U. du Q., 1974.

Bruchesi, J. Souvenirs à vaincre. Montréal, Qué., Editions Hurtuvise-HMH, 1974

Le Cegep 5 ans après: succès ou échec. Teach-in Cegep St-Laurent. Montréal, Qué., Les Grandes Editions du Québec, 1975

Collaboration. "Des éducateurs comment le rapport Roquet." Prospectives 7(2):83-4

Collin, C. et Osana, Z. L'enseignement de la philosophie. Essai de didactique expériementale. Montréal, Qué,, les Editions Fides 1974.

Desgroseilliers, P. "Le Cegep milieu de vie et le rôle des services aux étudiants." Prospectives 7(4):211-14

Fortin, J.-C. "La gestion du régime pédagogique des Cegep's." STOA 5(1):13-24

Gadbois, J. "L'élément étudiant dans l'évaluation institutionnelle." Prospectives $11(1): 39-44$

Gagnon, G. et al. Québec 1960-1980. La crise du développement. Anthologie des principaux textes sur ce problème. Montréal, Qué., Editions Hurtubise-HMH, 1974

Joly, J. M. "Le service d'admissions au collège et à l'université (SACU)". Prospectives $6(3): 150-54$

Langlois, J. "Sessions de sensibilisation aux grandes religions offertes au Cegep." Prospectives 6(3):146:49

Lazure, J. La jeunesse du Québec en révolution. Montréal, Qué., PUQAM, 1974

Lefebre, D. et Dupuy-Walker, L. "Rapport d'une expérience: cours de didactique centré sur l'étudiant." Prospectives 7(2):73-92

Lefevre, A. et Allard, M. Histoire du Canada à partir du Québec actuel. Montréal, Qué., Guérin Editeur, 1974

Legroulx, L. "L'enseignement professionnel collégial face au système coopératif." Prospectives 6(4):257-61

Lemire, G. "L'enseignement-recherche en linguistique au collégial." Prospectives 7(3):17175

Lipkin, J. P. "The academic 'tilt' in Quebec post-secondary education." Canadian and International Education 3(1):53-60

Longtin, J. L. et Massé, J. P. "L'enseignement télévisé modulaire; collégial". Prospectives 11(1):15-22

Rocher, G. Le Québec en mutation. Montréal, Qué., Editions Hurtubise-HMH, 1974

Sabourin, R. "Le Cegep dans son milieu." Prospectives 6(4):264-76

Sauvé, J.-C. "La régionalisation des Cegep: comment utiliserons-nous cet outil?" Prospectives 6(2):71-4

\section{III - AGENCIES AND GOVERNMENTAL DEPARTMENTS / ORGANISMES ET DEPARTMENTS GOUVERNEMENTAUX}

Baroux, J. "Canada provides a president, but only lukewarm support, for the World University." Science Forum 8(1):30-1

"Continuing innovation in information system." Science Dimension 6(6):4-7 
100 D. McCormack Smyth, Hazel Roberts, Pierre Casno

Hutchison, G. "Science eye in Ottawa." Canadian Research and Development 8(2):80 Lotz, J. "Funding for independent researchers: Artic Institute feels the crunch." Science Forum 8(2):26-8

Sheffield, E. "How Canada Council support is determined 'for' humanities and social sciences?" Univ. Aff / Aff. Univ. 16(9):8 